九州大学学術情報リポジトリ

Kyushu University Institutional Repository

\title{
Alpha-activity of Granite and Andesite Zircons from Southwest Japan measured with Nuclear
} Emulsion

Yamaguchi, Masaru

Faculty of Sciences, Kyushu University

https://doi.org/10.5109/1526115

出版情報：九州大學理學部紀要：Series D, Geology. 11 (1)，pp.49-59，1961-03-25. Faculty of Science, Kyushu University バージョン :

権利関係 : 
Mem. Fac. Sci., Kyushu Univ., Ser. D, Geology, Vol. XI, No. 1, pp. 49-59, text-figs. 1-3, tables 1-2, March 25, 1961

\title{
Alpha-activity of Granite and Andesite Zircons from Southwest Japan measured with Nuclear Emulsion*
}

By

\author{
Masaru YamaguchI
}

\begin{abstract}
Number of alpha-particles emitted from each minute grains of zircon separated from several granites and a hornblende andesite from southwest Japan have been counted with the Fuji ET-2E stripping type nuclear emulsion. Since the alpha-tracks are easily comparable under the microscope with other crystal features of zircon, the alpha-activity is effectively useful as a guide in classifying this mineral into several types, by which the behaviour of the minerals and the rocks may be clarified.

Some Cretaceous granites in southwest Japan contain zircons variable in colour, crystal habit and alpha-activity. Zircons associated with monazite or thorite in some granites are less radioactive than usual zircons.
\end{abstract}

\section{Introduetion}

Accessory zircon has been studied for many geological purposes : the crystal habit, elongation ratio, roundness and other crystal features are used as the provenance indicator in the well-known heavy mineral correlation method (Hutton 1950, WyATT 1954, Poldervaart 1956, Karakida 1954, Tomita and Karakida 1958, and many others), the mass colour of zircons are used in correlating granitic rocks (TомітA's "zircon correlation method"; TомiтA 1954), the lead and alpha-activity ratio (LARSEN et al., 1952, Матzко et al., 1958, etc.) or the pleochroic haloes (HaYASE 1954) are used for the age determination.

This paper will give a preliminary result of alpha-activity measurement made on each grain of zircon crops with the nuclear emulsion, the method of which is held in slight regard inspite of the recent advance in the quality of nuclear emulsion and the profitability for many works not attainable by the measurement with electrical counting instruments.

\section{Experimental Procedrre}

(1) Type of emulsion-The nuclear emulsions used in this study are alpha sensitive nuclear track plates designated as Fuji type ET-2 stripping plates obtained from the Fuji Photo Film Co. Ltd., in Tokyo, Japan. The emulsion is estimated to have the sensitivity intermediate between the Eastman NTA and NTB or approxi-

* Received January 10, 1961 
mately equal to the Ilford NR-C $\mathrm{C}_{2}$ or NR-B are 25 by 76 to 120 by 165 millimetres ( 1 by 3 to $4 \frac{3}{4}$ by $6 \frac{1}{2}$ inches) in size and 15, 30 and 50 microns in emulsion thickness. Of these emulsions, 25 by 76 millimetres in size with 50 microns thick was found to give a satisfactory result in the dispersed grain method used in this paper.

(2) Sample and plate preparation-Pure zircon crops most crystals being not crushed, were separated from granites and andesites of several localities in Japan by KARAKIDA and by the writer using the panning method (Tomita and Karakida 1956) and a Frantz isodynamic separator. Each sample was finally treated with warm concentrated hydrochloric acid for about 10 minutes.

The methods of plate preparation have been fully described by YAGODA (1949), Stieff and Stern (1952) and Koseki (1953), but a slightly modified method is used in this study as follows:

The glass slide, cleaned with a hot sodium hydroxide solution, was dipped in a hot solution of gelatin, which was prepared by putting 12 grams of gelatin in $150 \mathrm{ml}$. of distilled water allowing the gelatin to hydrate, and adding $2.5 \mathrm{ml}$. of 2 per cent chrome alum followed by gentle heating up to about $65^{\circ} \mathrm{C}$. After dipping the glass slide, it was dried, and then grains of zircon were dispersed on it fixing with several drops of 5 per cent gelatin solution and leaving it still on a flat table-surface until the gelatin set.

To soften the emulsion, the stripping plate was soaked in distilled water for several minutes, and the softened emulsion was carefully stripped off from the glass plate in the water. Now the zircon grains fixed with gelatin on the glass slide were covered with the emulsion just mentioned, surplus margins of the emulsion being folded back to the other side of the glass slide and fixed with a solution of a cement. The slide was then forced to hydrate in air current for several hours.

(3) Exposure-Each plate sealed up in a can with some amounts of absorbent (Adsol) was kept in a electric refrigerator at about $5^{\circ} \mathrm{C}$ for about a month. In the same run, uncovered thin sections of pitchblende were exposed on several contact type nuclear plates for about 5 to 30 minutes. Some of these exposed plates were developed immediately, and the rest of the exposed plates together with non-exposed plates were also kept in the same manner for the same duration with the sample plates, both of which were used for the correction of blank tracks and fading effects.

(4) Development-After the exposure, the plates were developed for about 25 minutes in Eastman D-19 developer at $19-21^{\circ} \mathrm{C}$, fixed in Fuji $\mathrm{FF}-\mathrm{H}$ fixer for about 3 to 4 hours and rinsed in distilled water for about 3 hours.

(5) Alpha-track counting-The developed plates were examined under the microscope at moderate magnifications $(\times 80-600)$ focusing into the emulsion. With the aid of ruled ocular disks (net micrometer), the number of alpha-tracks were counted, and the shapes of zircon grains were carefully drawn enlarged on section paper.

Since the emulsion is in direct contact with only about half of a zircon crystal 
(Fig. 1), the effective surface area ejecting alpha-particles which record tracks in the emulsion was estimated under the microscope by multiplying the apparent area of the crystal faces inclined to the optical axis of the microscope by the factor of inclination $(\operatorname{Sec} \theta)$. Most of the zircons have settled on the glass slide with the crystal face (a) or (m), the inclinations $(\theta)$ are $\widehat{\mathrm{am}}=45^{\circ}, \widehat{\mathrm{mp}}=47^{\circ} 50^{\prime}$, $\widehat{\mathrm{ap}}=61^{\circ} 40^{\prime}, \widehat{\mathrm{ax}}=31^{\circ} 43^{\prime}, \widehat{\mathrm{m} \mu}=20^{\circ} 12^{\prime}$.

Since counts of back ground tracks and fading effects are low within

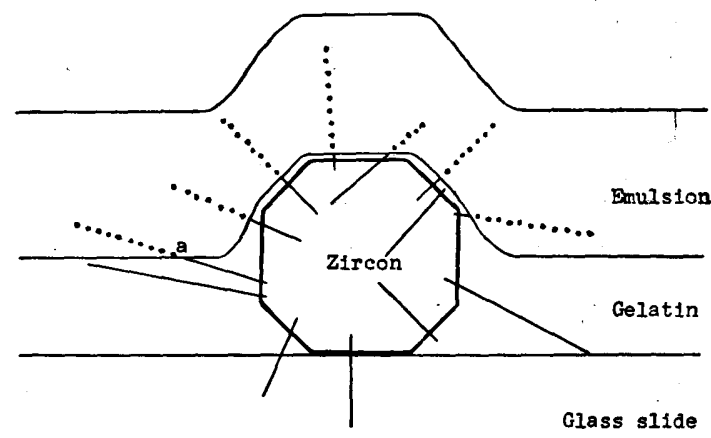

Fig. 1. Track registration from a zircon crystal (thick source) covered with the nuclear emulsion. Note that the end (a) of a track is the base of emulsion.

the experimental error, they were neglected in the counting of alpha-tracks of zircon.

\section{Alpha-activity of Zircon in Relation to Other Physical Properties}

(1) Length of alpha-tracks-Length of alpha-tracks ejected from zircon were measured under the microscope, and if necessary using a universal stage. It has been estimated (KOSEK1 1953) that the alpha-track lengths in the Fuji type ET-2E emulsion are 54 microns for $\mathrm{Th} \mathrm{C}^{\prime}$ and 44 microns for $\mathrm{Ra} \mathrm{C}$

Of these tracks from zircons dealt with in this study, most of them are shorter than 40 microns, about 30 microns being most abundant, while those longer than 45 microns are less abundant. These results may indicate that in the zircon the radioelements are mainly of U-series associated with those of less abundant Th series. In some samples, however, alpha-tracks longer than 45 microns were found crowding around some mineral grains, which are identified by this observation coupled with other physical properties as thorite and monazite, the last of which has already been given in detail by Karakida and Tomita (1954).

(2) Distribution of alpha-tracks-Alpha-tracks kave been observed surrounding zircons evenly. However, around inclusions, such as slender apatites, opaque grains or platy minerals, the alpha-tracks are sparsely populated. In addition, it is to be noted that no radiocolloid has been found. These facts may indicate that the principal source of radioactivity of the zircons investigated is not in these inclusions, but is distributed submicroscopically and uniformly in the zircon crystal; in other words, 'ТомгтA" opinion that " $\mathrm{Th}$ and/or $\mathrm{U}$ must be present diadochically replacing zirconium in the structure of zircon" (Tоміта 1954, p. 148) will find general acceptance.

(3) Colour, crystal habit and alpha-activity-Zircon grains separated from individual rock specimens may be divided, according to their colour, crystal habit and alphaactivity, into two or three groups as follows: one includes lighter coloured, euhedral crystals with lower alpha-activity and the other.two include deeper coloured, often 
turbid, ill-formed and often cracked crystals with higher alpha-activity :-zircons in the intermediate state of metamictization. Some details will be given in the next section.

(4) Brief notes on the samples-The materials dealt with in this study are tabulated in Table 1; the alpha-activity of zircon and associated monazite and thorite in the rocks is given in Table 2; the main crystal features are shown in Fig. 2.

Table 1. Name of rock sample, mass color of zircon and the approximate goelogical age.

\begin{tabular}{|c|c|c|c|c|}
\hline No. & Rock name & Mass color of Zircon & $\begin{array}{l}\text { Geological } \\
\text { Age }\end{array}$ & References \\
\hline 1. & Itoshima granodiorite & greish pink or violet & $\begin{array}{l}\text { Lower } \\
\text { Trias }\end{array}$ & $\begin{array}{l}\text { KARAKIDA \& TANEDA } \\
\text { (1950) } \\
\text { YAMASAKI et al. } \\
(1958)\end{array}$ \\
\hline 2. & $\begin{array}{l}\text { Dark inclusion in Ito- } \\
\text { shima granodiorite }\end{array}$ & grey yellow & $"$ & $"$ \\
\hline 3. & Kitazaki granodiorite & light pink & , & $"$ \\
\hline 4. & Sawara granite & $\begin{array}{l}\text { cclourless to yellow } \\
\text { (with abundant } \\
\text { monazite) }\end{array}$ & $\begin{array}{l}\text { Later } \\
\quad \text { Cretaceous }\end{array}$ & $\begin{array}{l}\text { TOMITA } \\
\text { YAMASAKI et al. } \\
(1958)\end{array}$ \\
\hline 5. & $\begin{array}{l}\text { Shōdoshima biotite } \\
\text { granite }\end{array}$ & grey greenish yellow & $\begin{array}{l}\text { Upper Creta- } \\
\text { ceous }\end{array}$ & YAMAGUCHI \\
\hline 6. & Yakushima granite & pink (with thorite) & $\begin{array}{l}\text { Lower to Mid- } \\
\text { dle Miocene }\end{array}$ & \\
\hline 7. & Gotō granite & red & " & $(1961)$ \\
\hline 8. & $\begin{array}{l}\text { Hornblende Andesite } \\
\text { on Shōdoshima } \\
\text { Island }\end{array}$ & colourles & $\begin{array}{l}\text { Upper } \\
\text { Pliocene }\end{array}$ & YAMAGUCHI \\
\hline
\end{tabular}

The locality, brief notes on rocks and zircons are given in the following:

1) Itoshima granodiorite: North of Ura, Shima-mura, Itoshima-gun, Fukuoka Prefecture. Collected by Y. KaraKida (It 213Z)

The rock (KARAKIDA and TANEDA 1950) is coarse-grained and schistose, consisting of hornblende, biotite, quartz, oligoclase and alkali-feldspar. Zircons separated from the rock (Itoshima zircon, TomiTa and KARAKIDA 1958) are greyish pink or violet in mass colour with rather uuiform grain size and uniform lower alpha-activity.

2) Dark inclusion in Itoshima granodiorite: Fukae, Nijyō-mura, Itoshima-gun, Fukuoka Prefecture. Collected by Y. Karakida (Ud 7BS ${ }_{2}$ )

The dark inclusion is composed of hornblende, biotite, quartz and andesine. Zircons separated from this inclusion are grey yellow in mass colour with uniform grain size and uniform lower alpha-activity.

3) Kitazaki granodiorite: Nishi-ura, Kitazaki-mura, Itoshima-gun, Fukuoka Prefecture. Collected by Y. Karakida (It 737Z)

The rock (KARADIDA and TANED,A 1950) is medium-grained, consisting of horn- 

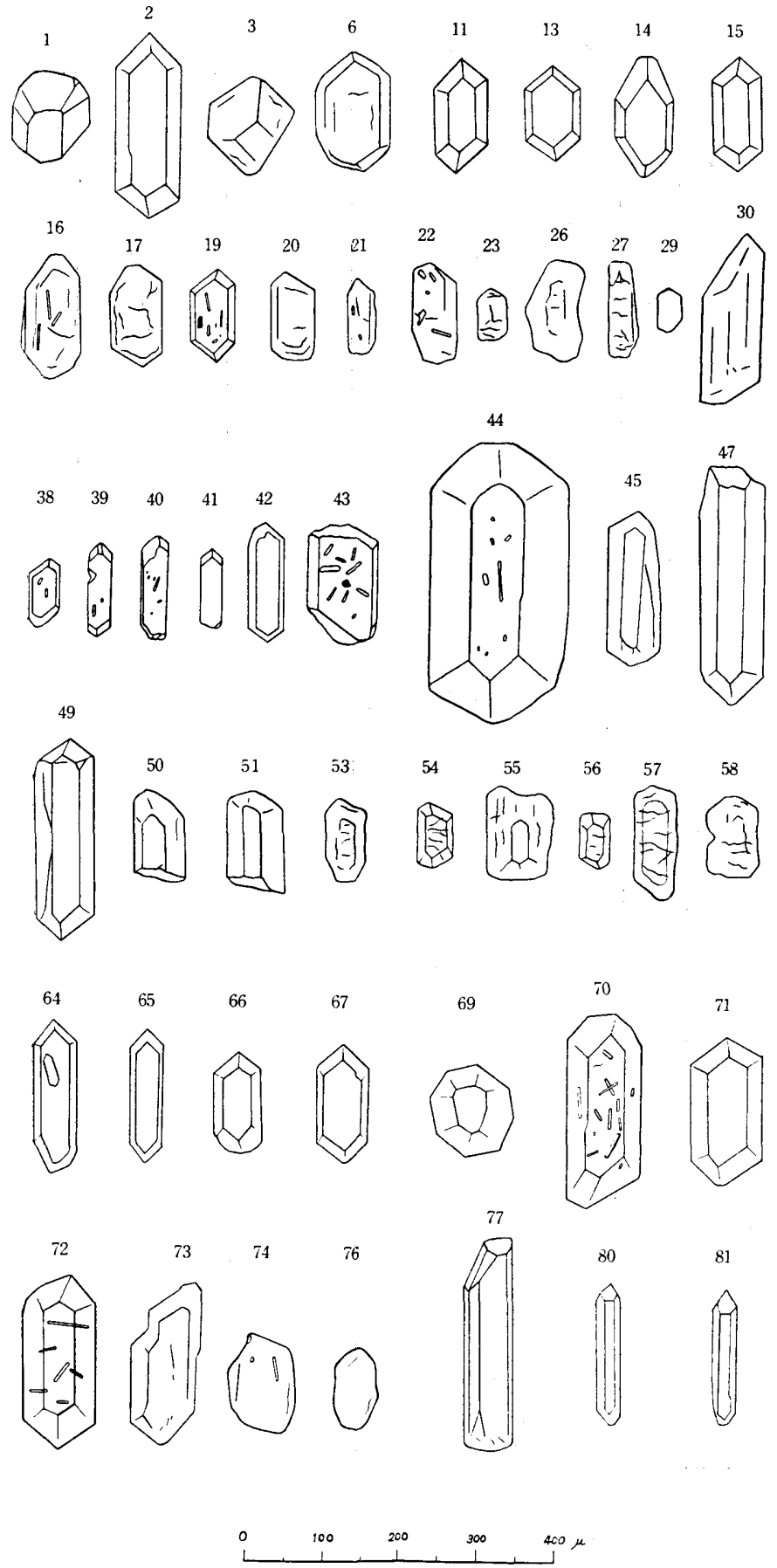

Fig. 2. Zircons in the granites and andesite, Southwest Japan, showing variation of crystal features. Drawn with the aid of net micrometer under the microscope. Numbers refer to Table 2. 
Table 2. Alpha-activity of zircons, and associated monazite and thorite in the granites and andesite, Southwest Japan.

\begin{tabular}{|c|c|c|c|c|c|c|c|}
\hline $\begin{array}{l}\text { Rock } \\
\text { Name }\end{array}$ & $\begin{array}{l}\text { Mineral } \\
\text { Name }\end{array}$ & $\begin{array}{l}\text { Number } \\
\text { and } \\
\text { Type }\end{array}$ & Colour in Grains & $\begin{array}{l}\text { Area } \\
\times 0.01 \\
\quad \mathrm{~mm}^{2}\end{array}$ & $\begin{array}{c}\text { Time of } \\
\text { Exposure } \\
\text { (hours) }\end{array}$ & $\begin{array}{l}\text { Number } \\
\text { of } \\
\alpha \text { tracks }\end{array}$ & $\begin{array}{c}\mathrm{T} \alpha(\alpha / \\
\left.\mathrm{cm}^{2} / \mathrm{sec}\right)\end{array}$ \\
\hline 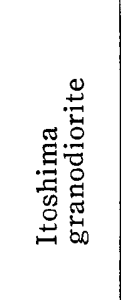 & - Zircon & $\begin{array}{r}1 \\
2 \\
3 \\
4 \\
5 \\
6 \\
7 \\
8 \\
9 \\
10\end{array}$ & $\begin{array}{c}\text { light violet } \\
\text { " } \\
\text { " } \\
\text { " } \\
\text { " } \\
\text { " }\end{array}$ & $\begin{array}{l}0.92 \\
1.68 \\
0.61 \\
0.66 \\
0.73 \\
1.18 \\
1.04 \\
1.12 \\
0.77 \\
0.77\end{array}$ & $\begin{array}{l}792 \\
" \\
" \\
" \\
" \\
" \\
" \\
"\end{array}$ & $\begin{array}{r}63 \\
115 \\
41 \\
48 \\
52 \\
85 \\
80 \\
85 \\
73 \\
75\end{array}$ & $\begin{array}{l}0.24 \\
0.24 \\
0.24 \\
0.25 \\
0.25 \\
0.25 \\
0.27 \\
0.30 \\
0.33 \\
0.34\end{array}$ \\
\hline 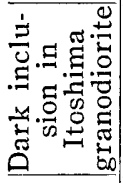 & Zircon & $\begin{array}{l}11 \\
12 \\
13 \\
14 \\
15\end{array}$ & $\begin{array}{c}\text { light yellow } \\
" \\
" \\
" \\
"\end{array}$ & $\begin{array}{l}0.83 \\
0.91 \\
0.68 \\
0.84 \\
0.76\end{array}$ & ", & $\begin{array}{l}45 \\
52 \\
40 \\
50 \\
48\end{array}$ & $\begin{array}{l}0.19 \\
0.20 \\
0.21 \\
0.21 \\
0.22\end{array}$ \\
\hline 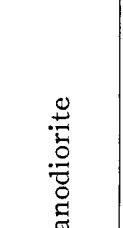 & & $\mathrm{A}\left\{\begin{array}{l}16 \\
17 \\
18 \\
19 \\
20 \\
21 \\
22\end{array}\right.$ & $\begin{array}{c}\text { light pink to violet } \\
\text { light pink } \\
" \\
" \\
" \\
"\end{array}$ & $\begin{array}{l}0.96 \\
0.75 \\
0.45 \\
0.53 \\
0.52 \\
0.31 \\
0.58\end{array}$ & $\begin{array}{l}\text { ", } \\
\text { ", } \\
\text { ", }\end{array}$ & $\begin{array}{l}30 \\
40 \\
31 \\
36 \\
38 \\
26 \\
50\end{array}$ & $\begin{array}{l}0.11 \\
0.20 \\
0.24 \\
0.24 \\
0.26 \\
0.29 \\
0.30\end{array}$ \\
\hline 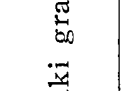 & Zircon & $\mathrm{B}\left\{\begin{array}{l}23 \\
24 \\
25\end{array}\right.$ & $\begin{array}{c}\text { dark pink } \\
", \\
"\end{array}$ & $\begin{array}{l}0.27 \\
0.21 \\
0.61\end{array}$ & ", & $\begin{array}{l}25 \\
20 \\
58\end{array}$ & $\begin{array}{l}0.32 \\
0.33 \\
0.33\end{array}$ \\
\hline న్ర & & 26 & dark orange & 0.72 & " & 70 & 0.34 \\
\hline 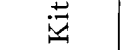 & & & $\begin{array}{l}\text { turbid red and } \\
\text { cracked }\end{array}$ & 0.40 & $"$ & 44 & 0.38 \\
\hline & & & & $\begin{array}{l}0.42 \\
0.15\end{array}$ & $"$ & $\begin{array}{l}46 \\
18\end{array}$ & $\begin{array}{l}0.40 \\
0.42\end{array}$ \\
\hline & & 30 & turbid orange & 1.39 & " & 55 & 0.14 \\
\hline \multirow{2}{*}{ 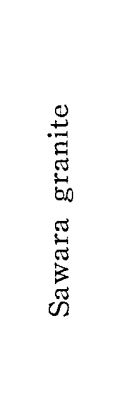 } & 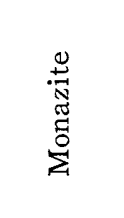 & $\begin{array}{l}31 \\
32 \\
33 \\
34 \\
35 \\
36 \\
37\end{array}$ & $\begin{array}{c}\text { green } \\
\text { yellow green } \\
\qquad, " \\
\text { orange green }\end{array}$ & $\begin{array}{l}0.46 \\
1.12 \\
0.57 \\
0.56 \\
0.31 \\
1.31 \\
2.12\end{array}$ & $\begin{array}{l}", \\
", \\
",\end{array}$ & $\begin{array}{r}74 \\
161 \\
106 \\
108 \\
61 \\
242 \\
510\end{array}$ & $\begin{array}{l}0.56 \\
0.62 \\
0.65 \\
0.68 \\
0.69 \\
0.71 \\
0.81\end{array}$ \\
\hline & Zircon & $\begin{array}{l}38 \\
39 \\
40 \\
41 \\
42 \\
43\end{array}$ & $\begin{array}{c}\text { pale pink } \\
\text { " } \\
" \\
" \\
"\end{array}$ & $\begin{array}{l}0.29 \\
0.36 \\
0.39 \\
0.23 \\
0.60 \\
1.23\end{array}$ & $\begin{array}{c}720 \\
" \\
" \\
" \\
",\end{array}$ & $\begin{array}{r}3 \\
4 \\
5 \\
3 \\
20 \\
40\end{array}$ & $\begin{array}{l}0.040 \\
0.043 \\
0.049 \\
0.500 \\
0.130 \\
0.142\end{array}$ \\
\hline
\end{tabular}


Table 2. (Continued)

\begin{tabular}{|c|c|c|c|c|c|c|c|}
\hline $\begin{array}{l}\text { Rock } \\
\text { Name }\end{array}$ & $\begin{array}{c}\text { Mineral } \\
\text { Name }\end{array}$ & $\begin{array}{c}\text { Number } \\
\text { and } \\
\text { Type }\end{array}$ & Colour in Grains & $\begin{array}{l}\text { Area } \\
\times 0.01 \\
\quad \mathrm{~mm}^{2}\end{array}$ & $\begin{array}{c}\text { Time of } \\
\text { Exposure } \\
\text { (hours) }\end{array}$ & $\begin{array}{c}\text { Number } \\
\text { of } \\
\alpha \text { tracks }\end{array}$ & $\begin{array}{c}\mathrm{T} \alpha(\alpha) \\
\left.\mathrm{cm}^{2} / \mathrm{sec}\right)\end{array}$ \\
\hline 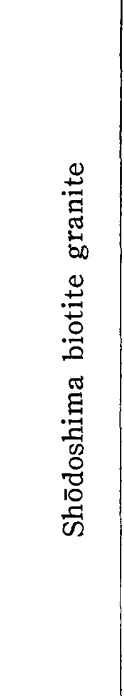 & Zircon & $\begin{array}{l}\text { a }\left\{\begin{array}{l}44 \\
45 \\
46 \\
47 \\
48 \\
49\end{array}\right. \\
\text { b }\left\{\begin{array}{l}50 \\
51 \\
52\end{array}\right. \\
\text { c }\left\{\begin{array}{l}53 \\
56 \\
54 \\
55\end{array}\right. \\
57 \\
58\end{array}$ & $\begin{array}{l}\text { colourless } \\
\text { light yellow } \\
", \\
", \\
\text { " } \\
\text { light greenish } \\
\text { yellow } \\
", \\
\text { slightly turbid } \\
\text { orange and } \\
\text { cracked } \\
\text { light orange } \\
\text { and cracked } \\
\text { slightly turbid } \\
\text { orange and } \\
\text { cracked } \\
\text { turbid orange } \\
\text { and cracked } \\
\text { light reddish } \\
\text { orange and } \\
\text { cracked }\end{array}$ & $\begin{array}{l}5.47 \\
1.18 \\
1.54 \\
2.28 \\
0.41 \\
1.67 \\
0.88 \\
0.66 \\
0.66 \\
0.54 \\
0.31 \\
0.93 \\
0.26 \\
0.71 \\
0.61\end{array}$ & $\begin{array}{l}714 \\
" \\
" \\
" \\
" \\
" \\
" \\
" \\
" \\
" \\
" \\
"\end{array}$ & $\begin{array}{r}114 \\
29 \\
46 \\
72 \\
14 \\
66 \\
\\
48 \\
45 \\
48 \\
67 \\
36 \\
109 \\
\\
36 \\
\\
111 \\
\\
100\end{array}$ & $\begin{array}{l}0.08 \\
0.10 \\
0.12 \\
0.12 \\
0.13 \\
0.15 \\
0.21 \\
0.27 \\
0.28 \\
0.43 \\
0.45 \\
0.46 \\
0.54 \\
0.61 \\
0.64\end{array}$ \\
\hline \multirow{2}{*}{ 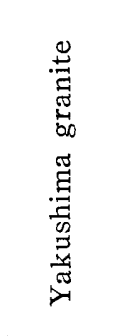 } & Thorite & $\begin{array}{l}59 \\
60 \\
61 \\
62 \\
63\end{array}$ & $\begin{array}{c}\text { light green } \\
\text { " } \\
\text { yellow green } \\
\text { ", }\end{array}$ & $\begin{array}{l}2.44 \\
2.35 \\
1.47 \\
0.67 \\
3.06\end{array}$ & $\begin{array}{l}792 \\
" \\
" \\
" \\
,\end{array}$ & $\begin{array}{l}256 \\
266 \\
168 \\
110 \\
557\end{array}$ & $\begin{array}{l}0.37 \\
0.39 \\
0.40 \\
0.57 \\
0.64\end{array}$ \\
\hline & Zircon & $\begin{array}{l}64 \\
65 \\
66 \\
67 \\
68\end{array}$ & $\begin{array}{c}\text { pale pink } \\
, " \\
, \\
, \\
\text { " }\end{array}$ & $\begin{array}{l}0.77 \\
0.65 \\
0.71 \\
0.84 \\
0.88\end{array}$ & $\begin{array}{l}720 \\
" \\
" \\
"\end{array}$ & $\begin{array}{l}11 \\
11 \\
13 \\
18 \\
21\end{array}$ & $\begin{array}{l}0.055 \\
0.065 \\
0.071 \\
0.083 \\
0.092\end{array}$ \\
\hline 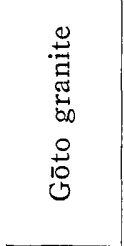 & Zircon & $\begin{array}{l}69 \\
70 \\
71 \\
72 \\
73 \\
74 \\
75 \\
76\end{array}$ & $\begin{array}{c}\text { reddish pink } \\
, " \\
" \\
\text { reddish brown } \\
" \\
"\end{array}$ & $\begin{array}{l}0.96 \\
2.07 \\
1.47 \\
1.72 \\
1.38 \\
0.83 \\
0.70 \\
0.54\end{array}$ & $\begin{array}{l}792 \\
" \\
" \\
" \\
" \\
" \\
"\end{array}$ & $\begin{array}{l}16 \\
41 \\
40 \\
53 \\
46 \\
58 \\
60 \\
49\end{array}$ & $\begin{array}{l}0.06 \\
0.08 \\
0.10 \\
0.12 \\
0.13 \\
0.27 \\
0.30 \\
0.32\end{array}$ \\
\hline 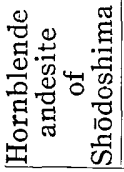 & Zircon & $\begin{array}{l}77 \\
78 \\
79 \\
80 \\
81\end{array}$ & $\begin{array}{c}\text { colourless } \\
" \\
" \\
" \\
"\end{array}$ & $\begin{array}{l}1.51 \\
1.02 \\
1.32 \\
0.54 \\
0.50\end{array}$ & $\begin{array}{l}714 \\
" \\
" \\
" \\
"\end{array}$ & $\begin{array}{l}52 \\
52 \\
78 \\
48 \\
53\end{array}$ & $\begin{array}{l}0.14 \\
0.20 \\
0.23 \\
0.35 \\
0.41\end{array}$ \\
\hline
\end{tabular}


blende, biotite, quartz, oligoclase and alkali-feldspar. Zircons of this rock may be divided into the following three types:

(A) light pink to light violet coloured, euhedral crystals, often containing inclusions and having lower alpha-activity,

(B) dark pink coloured, subhedral, smaller grains with higher alpha-activity,

(C) reddish to turbid orange zircon, often cracked, with higher alpha-activity; the turbid orange zircon often records long range alpha-tracks, indicating higher content of thorium.

4) Sawara granite: Otoishi, Kanatake-mura, Sawara-gun, Fukuoka Prefecture Collected by Y. KARAKIDA (Nt 85S)

The Sawara granite (KARAKIDA 1954, YAMASAKI et al. 1958) is coarse-grained, consisting of biotite, quartz, albite with subordinate muscovite and porphyritic orthoclase. The abundant heavy mineral, yellow green in colour, has been identified by X-ray study as monazite (Karakida and Tomita 1954). The mineral shows higher alphaactivity with abundant long range alpha-particles, indicating the higher content of thorium. Strictly speaking, colours range from green through yellow green to orange green, in the order of increasing alpha-activity. Zircons in this rock are euhedral, pale yellow and transparent, giving feeble alpha-activity.

5) Shōdoshima biotite granite: South of Ikeda, Ikeda-machi, Shōdoshima Island, Kagawa Prefecture. Collected by M. YAmaguchi (Sd K 13-A)

The rock is coarse-grained and leucocratic, consisting of biotite, quartz, albite and alkali-feldspar. Zircons in this rock show wide variation in their physical characters. Colours of each grain range from colourless through yellow to greenish yellow, orange, turbid orange and reddish orange in the order of increasing alphaactivity. For convenience, the relation between colour and alpha-activity is shown in Fig. 3. These zircons may be divided into 3 groups as follows :

(A) colourless to light yellowish and light brownish yellow, euhedral, long prismatic crystals with lower alpha-activity,

(B) light greenish yellow fragmental crystals with moderate alpha-activity,

(C) orange to turbid orange or reddish orange euhedral or subhedral, often cracked, smaller grains with higher alpha-activity.

6) Yakushima granite: Kosugi-tani, Yakushima Island, Kagoshima Prefecture. Collected by T. Arita (TA 48050401)

The rock is composed of biotite, quartz and oligoclase-albite, associated with porphyritic orthoclase. The accessory heavy minerals in this rock are of two kinds; one is pale pink, euhedral zircon with very low alpha-activity and the other is light greenish yellow, subhedral grains, ejecting long range alpha-particles. Since the mineral of the second type is an uniaxial and optically positive crystal with high content of thorium, it may be a thorite

7) Goto granite: Fukae-jima, Goto Island, Nagasaki Prefecture. Collected by Y. UEDA (Gh 594)

The rock is medium-grained, consisting of biotite, quartz, plagioclase and alkalifeldspar. Zircons in this rock consist of two kinds: one is pink to reddish pink, euhedral crystal with low alpha-activity, and the other reddish brown, subhedral 


\section{(a) Shôdoshima biotite granite}

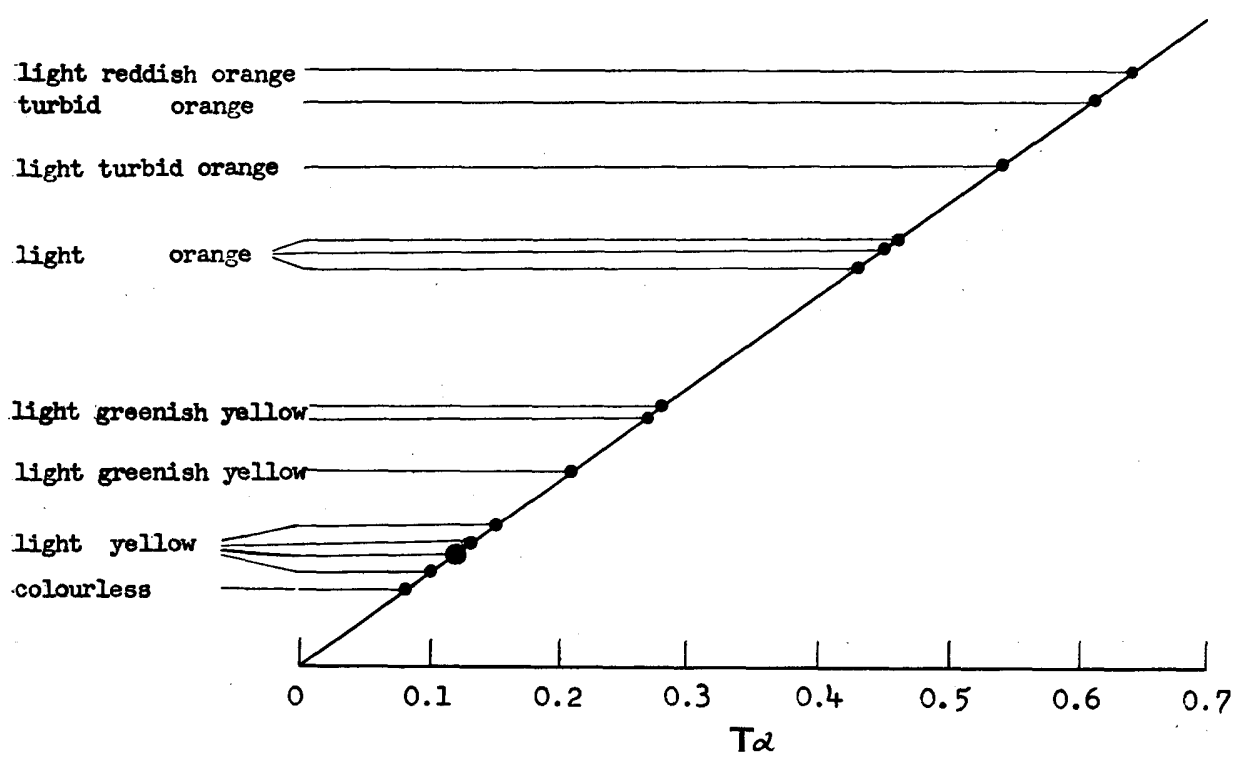

(b) Kitazak1 granodlorite

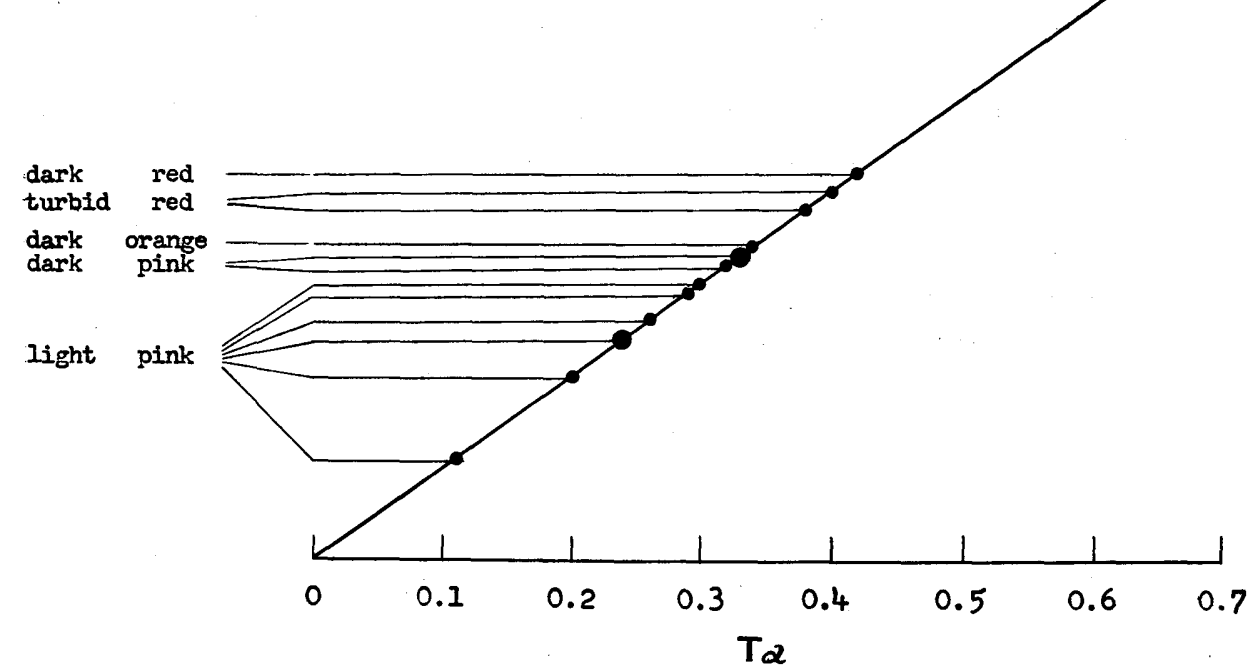

Fig. 3. Relation between alpha-activity and colour in zircon grain in a single rock.

grain with high alpha-activity:

8) Hornblende andesite on Shōdoshima Island : lava of Mikasayama at Kankakei, Shõdoshima Island, Kagawa Prefecture. Collected by M. YAmaguchi (Sd 605)

The rock contains phenocrysts of hornblende and labradorite in the groundmass composed of plagiociase, clino- and ortho- pyroxenes, magnetite and glass. Zircons 
separated from this rock, very small in amounts, are nearly colourless, long prismatic, euhedral crystals with moderate alpha-activity.

\section{Summary}

With the aid of nuclear emulsion, alpha-activity of each grain of the zircons are compared with other crystal features of them. Although the radioelement contents in these zircons are not so high, the method used in this paper has proved to be an measure in classifying the zircons as shown in Table 2. In short, transparent, light coloured, euhedral zircons are low in alpha-activity, while deeper coloured, often turbid, ill-formed and often cracked zircons show high alpha-activity-this accords with the previous observations by Hutron (1950), Butrlar et al. (1951), and Hayase (1954). The range of variation in alpha-activity of zircons differs in different rock typesthe fact may involve important petrographic meaning concerning the problem of the initial content of radioelements in magma, say in granitic magma, or their concentration during crystallization of the magma or some other processes. In this connection, it is particularly worthy of notice that a wide variation is observed in the accessory zircons of a single granitic rock from Shōdoshima Island or from Kitazaki, which are regarded as of Cretaceous age.

Zircons associated with monazite or thorite in the granites of Sawara and Yakushima are feebly radioactive than those from other localities.

The zircons dealt with in this study differ in hue and brightness of colour from those of different geological age. This has been the basis of Tomita's “zircon correlation. method." The difference in dilute colour of zircons has been explained by Tomita (1954) as the difference in the combined result of the strength of radioactivity and the length of irradiation-time. Although some difficulties may lie in verifying TомітA's hypothesis until an absolute and delicate colour scale as well as precise geological age would be determined, it is noted that, so far as the accessory zircons of a single rock, the colours arranged according to increasing radioactivity manifests an order which accords, as clearly seen in Fig. 3, with a part of the colour order given by Tомiта.

\section{Acknowledgments}

I wish to express my hearty thanks to Professor Tōru Tomita for his helpful suggestions and constructing criticism during this study and correcting my English writing, to Mr. Yoshifumi Karakida for supplying zircon samples, to Messrs. Hirosato Үамамото and Hitoshi Momor for their help in carrying experiment. I am greatly indebted to Mr. Yasuo Koseri of the Research Laboratory of the Fuji Photo Film Co. Ltd., for supplying with Fuji ET-2E nuclear plates. This work was partly financed by the Grant in Aid for Scientific Researches from the Ministry of Education, Japan. 


\section{References}

Buttlar, H.v., und Houtermans, F. G. (1951): Photographyische Messung des U- und ThGehaltes nach der Auflagemothode. Geochim. Cosmochim. Acta, 2, 43-61.

HAYASE, Ichikazu (1954a): Relative geologic age measurements on granites by pleochroic haloes and the radioactivity of the minerals in their nuclei. Am. Mineral., 39, 761-772.

(1954b) : Uranium content of zircons in granite. Mineral. Jour., 1, No. 3, 147-159.

Hurley, P. M., and Fairbairn, H.W. (1953): Radiation damage in zircon: A possible age method. Bull. Geol. Soc. Amer., 64, 659-674.

Hutton, C. O. (1950): Studies of heavy detrial minerals. Bull. Geol. Soc. Amer., 61, 635-710.

KARAKIda, Yoshifumi and TANeda, Sadakatsu (1950): Plutonic rocks of the Itoshima Peninsula, Fukuoka Prefecture (Abstract in Japanese). Jour. Geol. Soc. Japan, 56, 267.

(1954): The presence of "zircon zone" along a Cretaceous granodiorite-granite contact in North Kyushu (in Japanese). Jour. Geol. Soc. Japan, 60, 517-532.

- and TомітA, Toru (1954): Discovery of granites with abundant monazites (in Japanese). Bull. West Japan Branch Geol. Soc. Japan, No. 15, p. 11.

Koseki, Yasuo (1953): Autoradiography (in Japanese). Kagaku, 23, 150-155.

Larsen, E.S., Jr., Keevil, N.B., and Harrison, H.C. (1952): Method for determining the age of igneous rocks using the accessory minerals. Bull. Geol. Soc. America, 63, 10451052.

MAtzko, J. J., JAFFe, H.W., and WARing, C.L. (1958): Lead-alpha age determinations of granitic rocks from Alaska. Am. Jour. Sci., 256, 529-539.

PoldervaArt, A. (1956): Zircon in rocks. 2, Igneous rocks. Am. Jour. Sci., 254, 521-554.

StiefF, L. R., and Stern, T.W. (1952): Preparation of nuclear-track plates and stripping films for the study of radioactive minerals. Am. Mineral., 37, 184-196.

TAmita, Toru (1954): Geologic significance of the color of granite zircon, and the discovery of Pre-Cambrian in Japan. Mem. Fac. Sci., Kyushu Univ., Ser., D, Geol., 4, 135-161. - (1956): Radioeffect in Zircon (in Japanese with English abstract). Earth Science (Chikyu Kagaku), No. 26-27, 36-51.

and KARAKIDA, Yoshifumi (1956): Simple separation method of accessory zircon (in Japanese). Earth Science (Chikyu Kagaku), No. 29, 20-26.

(1958): Source identification of some granitic xenoliths in volcanic rocks. Mem. Fac. Sci., Kyushu Univ., Ser. D, Geol., 8, 25-34.

UEda, Yoshiro (1961): A study of the Goto group (in Japanese with English abstract). Sci. Report, Fac. Sci., Kyushu Univ., Geol. 5, (2), 51-61.

WyAtT, Michael (1954): Zircons as provenance indicators. Am. Mineral., 39, 983-993.

YAGODA, Herman (1949): Radioactive measurements with nuclear emulsions. John Wiley \& Sons, Inc., New York, 356 pp.

Yamaguchi, Masaru (1958): Petrography of the Otozan Flow on Shodoshima Island, Setouchi Inland Sea, Japrn. Mem. Fac. Sci., Kyushu Univ., Ser. D, Geol., 6, 217-238.

Yamasaki, Mitsuo, Matsushita, Hisamichi, Urata, Hideo, Karakida, Yoshifumi, Yamamoto, Hirosato, Ohara, Jyonosuke, and Iwahashi, Toru (1958): Geology and groundwater of Fukuoka City, I. Fukuoka City Office. 1-34. 